NBER WORKING PAPER SERIES

\title{
THE EFFECT OF THE MINIMUM WAGE \\ WHEN IT REALLY BITES: A \\ REEXAMINATION OF THE EVIDENCE \\ FROM PUERTO RICO
}

Alan B. Krueger

Working Paper No. 4757

\section{NATIONAL BUREAU OF ECONOMIC RESEARCH \\ 1050 Massachusetts Avenue \\ Cambridge, MA 02138 \\ June 1994}

I am grateful to Alida Castillo-Freeman for providing cross-industry data and to David Card, Kevin Lang, Richard Freeman, Richard Burkhauser and Robert Smith for helpful comments. Helpful comments were also received from participants at the Eastern Economic Association Meetings and the Comell-Princeton Third Annual Policy Conference. The usual disclaimer applies. This paper is part of NBER's research program in Labor Studies. Any opinions expressed are those of the author and not those of the National Bureau of Economic Research. 


\title{
THE EFFECT OF THE MINIMUM WAGE \\ WHEN IT REALLY BITES: A \\ REEXAMINATION OF THE EVIDENCE \\ FROM PUERTO RICO
}

\begin{abstract}
This paper reinvestigates the evidence on the impact of the minimum wage on employment in Puerto Rico. The strongest evidence that the minimum wage had a negative effect on employment comes from an aggregate time series analysis. The weakest evidence comes from cross-industry analyses. The main finding of the paper, however, is that the statistical evidence of a negative employment effect of the minimum wage in Puerto Rico is surprisingly fragile.
\end{abstract}

\author{
Alan B. Krueger \\ Department of Economics \\ Princeton University \\ Princeton, NJ 08544 \\ and NBER
}


The neoclassical model makes clear predictions about the impact of a binding minimum wage. Sectors that are forced to raise wages in response to a minimum should reduce employment because of both substitution and scale effects. In addition, firms will try to avoid the impact of a wage floor by reducing fringe benefits, not complying with the law, charging "key" fees, etc. When permitted by law, a subminimum wage should be used by any firm that previously hired eligible workers at a wage below the minimum wage. Although this model of the minimum wage is presented in almost every introductory economics textbook, much recent research challenges these predictions.' Consider the following findings:

1. Time-series regression models that have traditionally been used to measure the impact of the minimum wage on teenage employment in the U.S. no longer find a statistically significant effect of the minimum wage when data from the 1980s are added (see Wellington (1991) and Klerman (1991)). The results are even more puzzling for nonwhite workers, who have lower wages and would thus be expected to incur more disemployment as a result of minimum wage hikes. Estimating the same specifications that were estimated in the past, Wellington finds a positive (but insignificant) relationship between the employment rate of nonwhite teenagers and the coverage-weighted minimum wage.

2. Case studies of the fast food industry in Texas, Mississippi, North Carolina, New Jersey and Pennsylvania find that employment did not decline at establishments that were forced

\footnotetext{
${ }^{1}$ Not all of the recent empirical literature finds anomalous results, however. For example, see Taylor and $\operatorname{Kim}(1993)$.
} 
to raise wages by the minimum compared to others that were not (Katz and Krueger (1992), Card and Krueger (1994), and Spriggs et al. (1992)). If anything, these studies find that employment increased in restaurants that were forced to raise their wages to meet the new minimum wage in the short run. Card (1992) reaches a similar conclusion in a cross-state study of the relationship between the teenage employment rate and the fraction of the work force affected by minimum wage increases.

3. A cross-industry study of employment growth and minimum wage changes in the U.K. (where industry councils set minima) by Machen and Manning (1994) concludes that the minimum wage has not had an adverse impact on employment. If anything, employment growth is positively related to minimum wage growth in this study, although the effect is statistically insignificant.

4. Several studies have found that youth subminimum wages are hardly ever used by employers in the U.S. For example, Katz and Krueger (1992) find that less than $5 \%$ of Texas fast food restaurants used the youth subminimum wage in 1991. (See also Freeman, et al. (1981), Spriggs, et al. (1992), and BNA (1993)).

5. There is a sizable spike in the wage distribution at the minimum wage. Brown (1988) notes that the spike is an indication that people with presumably different ability levels earn the same wage, at variance with the assumptions of the standard model. Perhaps even more puzzling, there is a spike in the wage distribution at the minimum wage even for firms that 
are exempt from the minimum wage (Fritsch (1981)).

In spite of these anomalous findings for the U.S., it often is argued that when the minimum wage really bites into the wage distribution -- when it far exceeds the equilibrium wage for a substantial fraction of the work force -- then the effects of the minimum predicted by the textbook model will surface. The most commonly cited case where the minimum wage really should, and does, matter is in Puerto Rico. Reynolds and Gregory (1965) and Castillo-Freeman (1992) provide analyses of the minimum wage in Puerto Rico. Their research is widely cited as supporting the predictions of the standard model in the case when the minimum wage really matters (e.g., Fleisher (1970), Hamermesh and Rees (1993) and Ehrenberg and Smith (1994)).

How can these diverse findings for the U.S. and Puerto Rico be reconciled? I see three possibilities. 1) The recent wave of studies that conclude the minimum wage has not had an adverse impact on employment are somehow wrong, perhaps biased by misspecified equations, unobserved product demand shocks, and the like. The textbook model is everywhere and always true. 2) The minimum wage has the predicted effects when it is really high relative to the equilibrium wage, but it has little effect when it is low relative to the equilibrium wage. In other words, the textbook model only "works" when we have a "really big" distortion. At U.S. levels, we need to expand our model of the labor market to include features like job search, dynamic monopsony, equity, X-inefficiency, and efficiency wages to capture the anomalous results. 3) There is something wrong with the evidence from Puerto Rico. Even in an economy where the minimum wage really bites, the 
predictions of the textbook model may not hold.

This paper reexamines the evidence on Puerto Rico, starting with Lloyd Reynolds and Peter Gregory's classic 1965 study. Although Reynolds and Gregory have been frequently cited as support for the standard model of the minimum wage, their evidence on the employment effect of minimum wages is surprisingly mixed. Moreover, Reynolds and Gregory conclude that minimum wage increases in Puerto Rico often brought about large efficiency improvements in companies with the same capital and labor. Castillo-Freeman and Freeman provide a more modern analysis of Puerto Rico's experience. A reanalysis of their aggregate time-series data provide support for a disemployment effect of the 1974 minimum wage increase in Puerto Rico, but there is no evidence that the 1966-67 increase in the minimum of comparable magnitude, or the 1968-73 decrease in the minimum, had any discernable effect on employment. Perhaps more significantly, the cross-industry panel analysis of Castillo-Freeman and Freeman is found to be extremely sensitive to plausible, minor changes in specification. Indeed, just estimating Castillo-Freeman and Freeman's specification by weighted least squares (WLS), instead of ordinary least squares (OLS), changes the sign of the minimum wage variable. The basic conclusion of this paper is that the evidence on minimum wage effects stemming from Puerto Rico is quite fragile.

\section{The History of Minimum Wages in Puerto Rico ${ }^{2}$}

The institutions determining Puerto Rico's minimum wage rate are governed by the

\footnotetext{
${ }^{2}$ This material borrows heavily from Reynolds and Gregory (1965) and Castillo-Freeman and Freeman (1992).
} 
U.S. Congress. When the Fair Labor Standards Act (FLSA) took effect in 1938, it initially applied to Puerto Rico as well. Employers in Puerto Rico were required by law to pay the U.S. minimum wage of 25 cents per hour, which exceeded average wages on the island by perhaps $100 \%$. Noncompliance with the minimum wage was widespread, and a number of businesses threatened to close if the minimum wage was enforced. Congress recognized the problems of enforcing such a high minimum wage in Puerto Rico, and passed an amendment to the FLSA in June of 1940 that established tripartite industry committees to set separate minimum wages at the industry and occupation level. Between 1940 and 1974 , amendments to the FLSA expanded coverage to new industries in Puerto Rico, but industry committees continued to determine minimum wage rates.

The tripartite industry committees were composed of representatives of industry, labor and the public, drawn from both Puerto Rico and the mainland. Each committee made recommendations to the Administrator of the Wage and Hours Division of the U.S. Department of Labor, who was authorized to accept the committee's recommendations or appoint another committee to rehear the case. The first committees set minimum rates around 20 cents, much lower than the mainland minimum, which by then had risen to 30 cents. Nevertheless, Reynolds and Gregory conclude that the industry minima led to a substantial increase in hourly earnings in Puerto Rico.

Union leaders and some mainland employers charged that the Puerto Rican tripartite system did not raise minimum wages fast enough. In response to these criticisms, changes in the mid 1950s reduced the Secretary of Labor's authority to interfere with Puerto Rican minimum wages. In particular, tripartite committee recommendations were put into place 
much quicker, which weakened employers' ability to appeal minimum wage increases.

Amendments to the FLSA in 1974 and 1977 introduced a new policy of increasing coverage and enacting automatic increases in Puerto Rico's minimum wages to gradually bring them in line with U.S. levels. By 1983, Puerto Rico effectively had the same minimum wage as the U.S.

The minimum wage has had an overwhelming impact on the wage distribution in Puerto Rico. According to Reynolds and Gregory, $46 \%$ of export industries with available data employed at least half of their workers at exactly the minimum wage in 1955, and 75 percent of industries paid over half their workers within 5 cents of the minimum (see Table $2-4$, p. 54). In 10 percent of industries, the average wage approximately equalled the minimum wage. Reynolds and Gregory conclude "there are strong indications that the minimum wage system has been partially responsible for the rapid increase in the real wage level, the diverse movement of wages in individual industries, and the shrinkage of occupational differentials" (p. 80).

Castillo-Freeman and Freeman similarly document an impressive impact of the minimum wage on the wage structure with Current Population Survey data. A large spike in the Puerto Rican wage distribution at $\$ 2.90$ is evident in 1979 , when $50 \%$ of workers were covered by the U.S. minimum of $\$ 2.90$. Once all Puerto Rican industries became covered by the U.S. minimum wage, the U.S. minimum wage became the modal wage paid on the island. In 1983, one-quarter of Puerto Rican workers were paid within 5 cents of the U.S. minimum wage of $\$ 3.35$. In $1988,28 \%$ of workers were paid within 5 cents of $\$ 3.35$ per hour, even though the average wage on the island rose in nominal dollars. 
One metric for comparing the impact of the minimum wage on the wage structure in Puerto Rico is to compare it to the mainland. In the U.S. in 1989,17 percent of teenage workers earned within 5 cents of the minimum wage, of $\$ 3.35 .^{3}$ Thus, in the late $1980 \mathrm{~s}$ the minimum wage in Puerto Rico was more binding on the entire labor force in Puerto Rico than it was on the teenage labor market in the U.S.

\section{What Did Reynolds and Gregory Actually Find?}

Reynolds and Gregory's classic work on Puerto Rico is often cited as evidence that the minimum wage had dire consequences for Puerto Rican employment. This interpretation is somewhat ironic because Reynolds and Gregory reach a decidedly mixed conclusion about the impact of the minimum wage in Puerto Rico.

Reynolds and Gregory provide three pieces of evidence on the impact of minimum wages on employment in Puerto Rico, two of which have been largely ignored in the subsequent literature. First, they find a positive but insignificant correlation $(r=.151)$ between changes in production worker average wages and changes in employment across 36 Puerto Rican manufacturing industries between 1954 and 1958. Given that Reynolds and Gregory attribute industrial wage growth in Puerto Rico largely to minimum wage increases, this finding is inconsistent with the expected adverse employment effect of minimum wages. However, Reynolds and Gregory argue that this positive correlation "reflects the fact that the minimum wage setting procedure tends to push wages up fastest in the most profitable industries, which are also. those experiencing a rapid rightward shift

\footnotetext{
${ }^{3}$ See Katz and Krueger (1990).
} 
of demand schedules and, therefore, the largest expansion in employment" (p. 96).

The second piece of evidence presented by Reynolds and Gregory involves the estimation of an employment demand equation. This evidence may appear primitive by r.cdern econometric standards, but it has proven to be the most influential aspect of Reynolds and Gregory's work. Specifically, Reynolds and Gregory estimate the following equation by OLS:

$$
\frac{d X}{\not z 2\left(X_{0}+X_{1}\right)}-\frac{d N}{\not z\left(N_{0}+N_{1}\right)}=a+b \frac{d W}{\not 2\left(W_{0}+W_{1}\right)}
$$

where $\mathrm{X}$ represents value added in the industry, $\mathrm{N}$ represents employment of production workers, and $\mathrm{W}$ represents the production worker annual wage bill divided by the number of production workers (N). The justification for the particular form of the dependent variable is that labor demand may have shifted in some industries. Under the assumption of constant returns to scale, one could subtract off growth in output to estimate the substitution effect of wage changes holding output constant. Physical output is not available, so value added is used instead. Value added in manufacturing industries equals payroll plus profit plus capital payments. The negative of $b$ is interpreted as an estimate of the elasticity of substitution between labor and all other factors. The equation is estimated with cross-industry manufacturing data for each of two periods, 1949-54 and 1954-58."

Reynolds and Gregory were aware of several conceptual problems with this approach, and warn that their "findings must be interpreted with caution" (p. 101).

\footnotetext{
${ }^{4}$ Thirty-seven industries were included in the earlier period, and 50 in the latter.
} 
Importantly, they note that increasing returns may be a more natural assumption in their sample period. They also note that the assumption of a stable production function excludes technical progress. They were keenly aware that by holding output constant, they only estimated the substitution effect, and that minimum wages may have scale effects as well. Reynolds and Gregory ignore important statistical limitations of their approach. Most importantly, industrial value added is largely accounted for by payroll; this is especially true in a labor-intensive economy like Puerto Rico in the 1950s. As a consequence, since they have growth in payroll per worker on the right hand side of the equation, and growth in value added (approximately payroll) minus growth in workers on the left hand side, the coefficient $b$ will naturally be biased toward 1. The bias will be greater if profits and capital payments are small, or are a constant proportion of an industry's payroll over time.

This bias can most easily be seen in the logarithmic version of equation (1):

$$
\ln \left(\mathrm{X}_{1} / \mathrm{X}_{0}\right)-\ln \left(\mathrm{N}_{1} / \mathrm{N}_{0}\right)=\mathrm{a}+\mathrm{b} \ln \left(\mathrm{W}_{1} / \mathrm{W}_{0}\right)
$$

Recall that $\mathrm{X}$ equals payroll (WN) plus profit (denoted $\pi$ ) plus capital payments (denoted $\mathrm{r}$ ), $\mathrm{X}=\mathrm{WN}+\mathrm{r}+\pi$. Taking a second-order Taylor series expansion of $\ln (\mathrm{WN}+\mathrm{r}+\pi)$ around WN shows that the log of value added approximately equals $\ln (\mathrm{WN})+(\mathrm{r}+\pi) / \mathrm{WN}-$ $(r+\pi)^{2} / 2(\mathrm{WN})^{2}$. If $\mathrm{r}$ and $\pi$ are small relative to payroll, the left hand side of equation (2) is 
approximately $\ln \left(\mathrm{W}_{1} / \mathrm{W}_{0}\right)^{3} \quad$ Regressing $\ln \left(\mathrm{W}_{\mathrm{i}} / \mathrm{W}_{0}\right)$ on $\ln \left(\mathrm{W}_{1} / \mathrm{W}_{0}\right)$ will naturally bias $\mathrm{b}$ toward 1 .

Another source of bias in estimating equation (1) is that employment is likely to be measured with error, so dividing payroll by employment to derive wages will also induce a bias in b toward $1 .^{\circ}$ Current econometric practice probably would be to instrument for wage growth (using either the lagged wage or the change in the minimum wage) to overcome these biases. Unfortunately, Reynolds and Gregory do not present the underlying data that would permit the calculation of such alternate estimates.

Reynolds and Gregory's estimate of the labor demand elasticity is insignificantly different from -1 . In 1949-54 their estimated elasticity is -1.1 , and in 1954-58 it is -.92 , with standard errors of 13 and $.21 .^{7}$ Whether these estimates represent an output-constant demand elasticity is open to some question, however. In addition to the likely statistical biases noted above, one could question whether the (output-constant) labor demand elasticity is as large as -1 . First, most of the studies in Hamermesh's (1993) survey of labor demand find the substitution elasticity to be less than -1 . Second, a coefficient of -1 implies that half of manufacturing production workers were displaced by wage increases in Puerto Rico in the $1950 \mathrm{~s}^{8}$ Since the unemployment rate declined from $15.4 \%$ to $14.2 \%$

${ }^{5}$ Even if $(r+\pi) / W N$ is large, as long as it is constant within industries over time then first differencing will cancel out this term and its square, inducing a bias toward 1.

${ }^{6}$ Since employment appears on the left hand side, any omitted variables will induce a bias toward 1 because employment is in the denominator of the right hand side. Again, this c.1 most readily be seen with the log approximation to equation (1).

'The estimates of the intercept, a, are close to 0 , and not statistically significant.

${ }^{8}$ And this is an underestimate because it ignores the scale effect. 
between 1950 and 1958, it seems unlikely that the labor market was flooded by a new wave of fisplaced workers in this period. My own opinion is that the estimate is probably severely biased toward -1 , and that the exercise provides little evidence on the impact of the Puerto Rican minimum wage on employment.

The third component of Reynolds and Gregory's evidence consisted of a detailed study of the foundation garment industry. This was an important industry in Puerto Rico. Reynolds and Gregory devoted particular attention to the brassiere industry because this industry was large (accounting for one quarter of total U.S. production), and because brassieres were assembled by low skill workers and "not as susceptible to wide styling changes."

The minimum wage in the corset, brassiere and allied garments industry increased from 24 cents in 1950 , to 33 cents in 1951, to 55 cents in 1954, to 86 cents in 1960 , and to 99 cents in 1961 -- over a 400 percent increase. Average wages in the industry closely tracked the minimum wage, increasing from 29 cents in 1950 to 93 cents in 1960. Remarkably, production worker employment in the foundation garment industry increased nearly ten fold between 1951 and 1961 -- from 730 to 7,210. This pattern of employment growth is clearly at variance with an adverse employment effect of the minimum wage. Moreover, it is hard to argue that a product demand shock caused employment to rise because the product price fell between 1951 and 1961. 9 A product demand shock would be expected to affect employment via a rise in the price of output.

${ }^{9}$ The price per dozen units of garments shipped in Puerto Rico fell from $\$ 8.48$ in 1951 to $\$ 7.23$ in 1961 (see Table 3A-1). 
How did the industry manage to adjust to such dramatic wage changes? Reynolds and Gregory repor, "The main lines of adjustment have been through a rapid rise in productivity and a decline in profit margins" (p. 105). They document that dozens of garments shipped per production worker increased $250 \%$ in the decade between 1951 and 1961. They also document that operating profits as a percent of sales fell from 22 to 11 percent between 1953 and 1961. Thus, their explanation is a combination of productivity shock effects and transfers from firms to workers.

Their careful field study of productivity responses to the minimum wage suggested that turnover and absenteeism declined in response to minimum wage hikes, screening of job applicants improved, and "managerial effort" improved. Reynolds and Gregory write pointedly, "For the most part, these economies have not involved substitution of capital for labor; they have involved mainly a substitution of managerial ingenuity plus a higher level of effort by the supervisors and workers retained in the plant" (p. 193). They also note that it is possible to raise "standards of expected output" when the minimum wage rises, which in turn results in higher output per worker, "improved work flow and tighter supervision and discipline." On the other hand, their evidence suggests that the sizable productivity enhancements due to the minimum wage increases were not large enough to offset the decline in profit rates. But these industries were earning extranormal profits to begin with (compared to the mainland), so they continued to operate and even expanded employment. Reynolds and Gregory's bottom line is decidedly mixed. They found some regression evidence of capital-labor substitution in response to wage increases (subject to the criticisms above), but their direct observations led them to conclude that productivity 
increased in response to the minimum wage, and that key industries did not shrink despite dramatic increases in the minimum wage. Their evidence did not support a purely neoclassical interpretation or a purely institutional interpretation. In the end, Reynolds and Gregory were quite reluctant to recommend changes in the minimum wage system in Puerto Rico. They conclude, "In some Puerto Rico industries it may prove feasible to establish a minimum wage identical with that on the mainland," while, "In other industries, a lower Puerto Rican minimum may prove desirable" (p. 309).

\section{Modern Analyses of the Puerto Rican Minimum Wage}

Castillo-Freeman and Freeman's (1992) analysis of the Puerto Rican minimum wage consists of two components: (1) an aggregate time series analysis, and (2) an industry-level analysis. I consider each of these in turn.

\section{A. Aggregate Time Series Analysis}

Castillo-Freeman and Freeman analyze aggregate, annual time-series data for Puerto Rico from 1950-1987. ${ }^{10}$ They published the data in an appendix to their paper. Figure 1 uses their data to construct a plot of the employment-to-population rate and the Kaitz minimum wage index." The Kaitz index was constructed each year as:

$$
\Sigma f_{i}\left(m_{i} / w_{i}\right) c_{i}
$$

\footnotetext{
${ }^{10}$ Santiago (1989) also presents an aggregate time-series analysis of the minimum wage in Puerto Rico.

"Castillo-Freeman and Freeman report two series of the employment-to-population ratio. Throughout this paper I use series A. The figure looks quite similar if series B is used instead.
} 
where $f_{i}$ is the fraction of employment in industry $i, m_{i}$ is the minimum wage that applies to industry $i, w_{i}$ is the average hourly wage in industry $i$, and $c_{i}$ is the fraction of workers in industry $\mathrm{i}$ covered by the minimum wage. ${ }^{12}$ The Kaitz index has been widely used in U.S. studies of the minimum wage.

Figure 1 displays some interesting patterns. First, notice that the "coverageweighted" minimum wage increased sharply in the $1966-67$ period, but employment does not display any noticeable break in trend. Furthermore, the 1968-73 decrease in the minimum wage was not accompanied by (or followed by) a corresponding rise in employment. The main support for a negative employment effect of the minimum wage here is the 1974-75 minimum wage expansion period, which was accompanied by a discrete decline in employment relative to population. ${ }^{13}$

Table 1 presents an extension of the time-series regressions presented in CastilloFreeman and Freeman. Specifically, the $\log$ of the employment-to-population ratio is regressed on the $\log$ of the Kaitz index, the log of Puerto Rican GNP, the log of US GNP, a time trend, and corrected for a first-order autoregressive (AR(1)) term. Column (1) presents a replication of Castillo-Freeman and Freeman's main estimates. ${ }^{14}$ The Kaitz

\footnotetext{
${ }^{12}$ Castillo-Freeman and Freeman also use another measure of the minimum wage -- the average minimum dived by average hourly earnings times an economy-wide coverage measure. Both minimum wage measures have a negative effect on employment, and the effect with the Kaitz index tends to be larger in magnitude.

${ }^{13}$ Notice, however, that this period also coincided with the first OPEC oil price shocks and a sizeable recession in the mainland.

${ }^{14}$ Using the data published in Appendix A of Castillo-Freeman and Freeman I have been able to exactly replicate the minimum wage elasticity they report in Table 6.3 , column (1). However, some of the other coefficients are slightly different, and the R-square in column (1) is quite different. I estimated the models with the Cochrane-Orcutt procedure in STATA.
} 
index has a negative effect $(-.15)$, and is statistically significant. I explored several additional variants of this specification: omitting Puerto Rican GNP, including a quadratic time trend, estimating the equation separately for the pre and post-1973 data, and constructing a minimum wage index that does not involve coverage. Castillo-Freeman and Freeman try a number of alternative specifications as well. In general, the results continued to show a negative effect of the Kaitz index in these alternative specifications, although the size and significance of the coefficients varied.

One may question the direction of causality of minimum wages in Puerto Rico, however. Reynolds and Gregory, for example, were concerned that industry minima were selectively raised in industries where employment was expected to grow. In adJition, one might expect the minimum wage to matter with a time lag. To explore these issues, I included the contemporaneous minimum wage index, two lags of the index, and two leads of the index. These results are provided in column (2) of Table 1 and column (3) of Table 1 (without an autoregressive error correction). The leads of the minimum wage seem to matter as much as the lagged and contemporaneous values. Since minimum wage increases took effect quickly after they were enacted, it is unlikely that expectations of minimum wage increases caused employment to adjust in advance.

\section{B. Cross-Industry/Time Series Analyses}

The mainstay of Castillo-Freeman and Freeman's analysis is a cross-industry panel data analysis of employment. Their approach is to use pooled cross-industry/time-series data covering 42 industries from 1956-87 to estimate: 


$$
\ln \left(E M P_{i t}\right)=a+b \ln \left(c_{i r} m_{i r} / w_{i l}\right)+T_{1}+I N D_{i}+\mu_{i t}
$$

where $E M P_{n}$ is employment in industry $i$ in year $t, c_{i r} m_{i r} / w_{i t}$ is the Kaitz index for industry $i$ in year $t, T$, is a row vector of year effects. $I N D_{i}$ is a row vector of industry effects, and $\mu_{n}$ is an error term. Because unrestricted year and industry effects are included in this model, the impact of the coverage-adjusted minimum wage is identified by varying patterns in the minimum wage over time within industries. Castillo-Freeman and Freeman consider their industry-level analysis "a stronger test of the hypothesis that the minimum affected employment than thirty-one time-series observations" (p. 187). ${ }^{15}$

Column 1 of Table 2 exactly replicates Castillo-Freeman and Freeman's basic estimates for the post 1974 period. This specification shows a large, negative impact of the minimum wage index on employment, with a $\mathrm{t}$-ratio of -4.2 . Castillo-Freeman and Freeman suggest that the -.54 elasticity is likely to overstate the impact of the minimum on total employment because workers will shift from industries with large minimum wage increases to those with low increases.

Notice that the standard error of the regression in Column (1) is quite large for industry-level data (.48), suggesting a substantial amount of sampling variability in the dependent variable. Inspection of their data for selected industries revealed a huge amount of variability from year to year which is most likely due to noise in the data. An example of an industry with particularly noisy data is illustrated in Figure 2. The jagged pattern of log employment changes are most likely due to sampling variability and other sources of

\footnotetext{
${ }^{15}$ Their time-series regression actually has 37 observations.
} 
error.

A problem with estimating the specification in equation (3) by OLS is that the outlying industries have high leverage, and due to sampling variability and the log specification, smaller industries are likely to have much greater influence on the regression. ${ }^{16}$ Another problem is that the unweighted OLS estimates give far too much weight to manufacturing industries, since Castillo-Freeman and Freeman's sample consists of 37 detailed manufacturing industries and 5 one-digit non-manufacturing industries. In 1980 , manufacturing only accounted for $19.7 \%$ of Puerto Rican employment. ${ }^{17}$

To explore the robustness of the specification estimated by Castillo-Freeman and Freeman, I tried two obvious alternatives. First, I estimated equation (3) by weighted least squares, where the weights are the average industry employment over the period 1956-87. Second, I estimated equation (3) with the dependent variable in levels instead of logs. The results of these exercises, which are reported in Columns (2) and (3) of Table 1, are dramatically different from the base specification in column (1). The minimum wage coefficient becomes positive .07 if weighted least squares is used, with a t-ratio of 1.1.18 What's more, when estimated in levels the employment effect of the minimum wage is

\footnotetext{
${ }^{16}$ The residuals from equation (2) are highly heteroskedastic. For example, I regressed the squared residuals from equation (2) on the right hand side variables. The $\mathrm{R}^{2}$ from this regression is .49 , and the sample size times the $R^{2}$ follows a $\chi^{2}$ with 72 degrees of freedom. In this case the $\chi^{2}$ strongly rejects the null of homoskedasticity, with a value of 631 .

${ }^{17}$ See U.S. Department of Commerce (1984), p. 33.

${ }^{18}$ In estimates not reported here, I used an alternative set of weights. Specifically, I first estimated equation (2) by OLS. The squared residuals from the estimated OLS equation were then regressed on the explanatory variables. The square root of the predicted value from this auxiliary regression provided the weights for equation (2). In this case, the coefficient on the log Kaitz index became 1.9 with a t-ratio of 8.1 .
} 
again positive, now with a $t$-ratio of 6 ! This result is shown in column 3 . It is not clear which specification is to be preferred, but the disparate implications for the minimum wage variable are troubling.

Castillo-Freeman and Freeman report separate estimates for the pre- and post-1973 period. They put more weight on the post-1973 period because beginning in 1974 the Puerto Rican minimum wage was more closely linked to the U.S. minimum. My parallel estimates for the post-1973 period are presented in Table 3. Castillo-Freeman and Freeman's specification in column (1) shows a more negative effect of the minimum wage in this subperiod. But when the log-log specification is estimated by WLS, the minimum wage coefficient becomes slightly positive and statistically insignificant. The corresponding weighted estimate for the pre-1974 period is also .03 (S.E.=.06). When the model is estimated with employment measured in levels, the log of the Kaitz index has a negative effect that is less than half as large as its standard error $(t=.47)$. Also bear in mind that the standard errors reported here and in Table 2 are probably an underestimate because no attempt has been made to adjust for serial correlation in employment within industries. These results do little to overturn the puzzling results found for the full sample reported in Table 2.

Another specification check I tried involved including three leads, three lags, and the contemporaneous Kaitz measure in equation (3). The unweighted log-log regressions indicated that the lagged and contemporaneous Kaitz measures were jointly statistically insignificant ( $p$-value $=.69$ ). In fact, the three lags, contemporaneous value and two leads were jointly insignificant ( $p$-value=.21). Only the three-year-ahead Kaitz index was 
individually statistically significant in this regression. These results raise further questions about the causal effect of minimum wages on Puerto Rican employment even in the unweighted data.

Finally, I used Castillo-Freeman and Freeman's data to examine changes in employment over the period that the Puerto Rican minimum wage became linked to the U.S. level. Specifically, I split the data into three groups based on the 1973 Kaitz index: the bottom 25 percent, the middle 50 percent, and the highest 25 percent. The bottom 25 percent is the most affected by the increase in the minimum wage, and the highest group is the least affected. With this breakdown, I find the following percentage change in employment for industries between 1974 and 1983:

Kaitz Index in 1973:

Lowest 25 percent [Highest impact]

Middle 50 percent

Highest 25 Percent [Luwest impact]

\section{Percentage Growth in Employment, 1974-83 Mean Median} $-6 \%$ $-22 \%$ $-18 \%$

$$
-36 \%
$$
$-24 \%$

If anything, employment growth was greatest in the industries that should have been most negatively impacted by the increase in the Puerto Rican minimum wage in the 1974 83 period when the minimum was linked to the U.S. level. Notice, however, the large difference between the median and the mean growth rate of industry employment. This disparity is most likely a symptom of measurement error and sampling variance in the data. 
Nevertheless, these results provide little support for the conventional demand model.

\section{A Conceptual Problem with the Cross-Industry Approach}

How convincing should a cross-industry analysis be? Here I just want to highlight a problem that arises in the cross-industry analysis if all industries do not have the same elasticity of labor demand. ${ }^{19}$ Suppose there are two industries, denoted A and B. Industry A has an elasticity of demand for labor of -1 and industry $B$ has an elasticity of demand of -.5. Suppose industry $\mathrm{A}$ is a higher wage industry than industry B. Now consider the effect of a general minimum wage hike that raises wages by $5 \%$ in industry $\mathrm{A}$ and by $10 \%$ in industry $\mathrm{B}$ (because industry $\mathrm{A}$ is higher wage). The estimated effect of a minimum wage increase on employment in this case would be zero -- industry A and industry B would both shrink by 5 percent, even though they had different wage changes in response to the minimum wage. This is only a contrived example, and one could work out an example in which the employment effect of the minimum wage is bigger than the elasticity of demand in each sector (just reverse the elasticities of demand for industry A and B).

The point here is that the cross-industry studies rely heavily on the assumption that the elasticity of demand is constant across sectors, an assumption unlikely to hold. ${ }^{20} \mathrm{~A}$ similar problem arises in the time-series analyses; since industrial composition changes over time one would not expect the aggregate economy to have the same elasticity of demand over time. For these reasons, on methodological grounds I think one should have a

\footnotetext{
"Note that this problem applies to Reynolds and Gregory's cross-industry study as well.

${ }^{20}$ Indeed, the fact that different weighting of the industries produces dramatically different estimates in Tables 2 and 3 suggests the elasticity of demand varies across industries.
} 
preference for studies based on establishment-level data within-industries, where the assumption of a constant elasticity of demand across establishments is more plausible. In the future, it may prove very useful if such studies were conducted with Puerto Rican data.

\section{Garments and Related Industries -- An Update}

Reynolds and Gregory paid particular attention to the garment industries. Here I present a brief update of employment and wage trends in the textile, apparel and leather industries. In terms of employment, the apparel industry was, and still is, Puerto Rico's largest manufacturing industry, so any impact of the minimum wage on this industry would be of great importance to the island. Table 4a presents employment in the textiles, apparel, leather, and footwear industries in Puerto Rico in 1973, 1984 and 1992. Table 4b contains wage data for the same period. For a point of comparison, the tables also present employment and wages on the mainland U.S. in these same industries. The data are drawn from the ILO Yearbook of Labor Statistics.

Employment trends in these low-wage industries provides superficial support for the conventional wisdom in Puerto Rico. Between 1973 and 1984, employment declined by 66 percent in textiles, by 19 percent in apparel, and by 41 percent in leather. The combined employment in the four industries fell by 14,000 jobs between 1973 and 1984, which amounts to 25 percent of the initial level. However, a similar pattern of employment decline can be seen on the mainland for these same industries. For example, between 1973 and 1984, the combined employment in these industries on the mainland fell by 600,000 jobs, or 22 percent of the initial level. Between 1973 and 1992, employment in these 
industries declined by more in the mainland than in Puerto Rico. The qualitatively similar pattern of employment trends in these industries for Puerto Rico and the mainland suggests that factors other than the Puerto Rican minimum wage were at work.

Furthermore, the cross-industry pattern of employment and wage growth among these four industries within Puerto Rico provides little support for the conventional view. The lowest wage three-digit manufacturing industry in Puerto Rico in 1973 was the leather industry, closely followed by footwear. These industries experienced the greatest wage growth between 1973 and 1984 (both absolutely and relative to the mainland), probably in large part a result of linkage to the U.S. minimum wage. Yet the employment decline was much greater in textiles, where the average hourly wage in 1973 was just below the U.S. minimum of $\$ 2.00$, than in these two low-wage industries. And the footwear industry actually declined much more on the mainland than in Puerto Rico.

What explains the pattern of employment in the low-wage garment and relatedproducts industries? Industrial employment tends to go through a natural evolution during the course of development, with low-wage manufacturing jobs declining as a nation grows in wealth. The most obvious explanation for the pattern of employment shown in Table $4 \mathrm{a}$ is that Puerto Rico was undergoing rapid economic development in the 1970s and 1980s, and the development process naturally entailed industrial shifts out of low-wage manufacturing. These shifts in employment probably had little to do with the minimum wage. 
V. Conclusion

This paper has reinvestigated the evidence on employment effects of Puerto Rico's minimum wage. The strongest evidence that the minimum wage had a negative effect on employment in Puerto Rico comes from an aggregate time series analysis. The weakest evidence comes from cross-industry analyses. In general, however, I think one would have to consider the evidence surprisingly fragile. If one asks oneself, would an intelligent skeptic (say a sociologist) be persuaded of adverse employment effects of minimum wages by the evidence from Puerto Rico, I think the honest answer would be: unlikely.

Perhaps the conclusion that one should reach from this review of evidence is that the jury is still out on Puerto Rico's experience. In the meantime, it might make sense for economists to contemplate alternative models that can, in some instances, account for the limited, or even nonexistent, adverse employment effects of minimum wage increases. Along these lines, three factors strike me as having been particularly relevant for Puerto Rico. First, Reynolds and Gregory emphasize the inefficiency of production in Puerto Rico, and that the minimum wage may have shocked employers into realizing efficiency improvements. For example, consider the following passage from Reynolds (1965, p. 33) AER summary of his research:

If one defines the production function as embodying median current practice, one would have to say that the production possibilities frontier moved outward as the wage level rose. If on the other hand one defines the production function in terms of best available techniques (say, in this case, the performance of a superior mainland plant in the same industry), one would have to say that most Puerto Rican plants started off well within their production frontier and moved toward it as a result of wage pressure. 
If there was pervasive slack in Puerto Rican industry, one might expect that mainland employers could also improve production to lower costs in response to relatively modest minimum wage increases without cutting the work force. Indeed, Gary Gerdemann, a KFC spokesman recently said that his company has the ability to "engineer out" a onehalf percent cost increase by switching suppliers, reducing packaging, shipping materials in bigger lots, and changing recipes. ${ }^{21}$ This slack seems to exist even after a recent minimum wage hike. A major puzzle is why don't companies like KFC eliminate this slack even without the pressure of cost increases?

Second, massive disequilibrium strikes me as another possible consideration for interpreting Puerto Rico's experience in the 1950s. Mainland employers were setting up in Puerto Rico at a rapid rate. Wages in Puerto Rico were far below mainland levels, and e.r.ployers made extranormal profits on the island. Modern and outdated production technology were used at the same time; companies in the same industry earned a wide range of returns on their investments. It is at least possible that the wage in Puerto Rico was below its (temporary) equilibrium level. The minimum wage could have pushed wages more quickly toward their equilibrium level. In this case, the minimum may have helped the market to reach its ultimate equilibrium. Of course, this type of an explanation seems far less applicable to the mainland.

Third, in many industries there were relative few employers in Puerto Rico. These employers may have been able to monopsonize the labor market. For example, in the

\footnotetext{
${ }^{21}$ See New York Times, "Hädest Task of the 1990's: Raising Prices," March 1, 1994, p. D1.
} 
foundation garment industry there were only 10 firms in 1953, and 18 in 1961 (see Reynolds and Gregory, Table 3A-2). The low state of information and transportation technology may have made monopsony more plausible.

At this stage, these are just speculations about Puerto Rico's experience. Indeed, future research may well convincingly demonstrate that high minimum wages have resulted in diminished employment in Puerto Rico. I think most economists, the current author included, expect that at really high levels the minimum wage must reduce employment. That this proposition has been so hard to show may be more a statement about the difficulties of statistical analysis with available data, than about economic theory. 


\section{References}

Charles Brown, "Minimum Wage Laws: Are They Overrated?" 1988. Journal of Economic Perspectives, Vol. 2, Summer, pp. 133-47.

Bureau of National Affairs. 1993. "Few Employers Use Training Wage, According to Draft Report from DOL." Daily Labor Report. Washington, D.C. (March 18), pp. A6-A7.

Card, David. 1992. "Using Regional Variation in Wages to Measure the Effects of the Federal Minimum Wage." Industrial and Labor Relations Review, Vol. 46, No. 1 (October 1992), pp. 22-37.

David Card and Alan Krueger. 1994. "Minimum Wages and Employment: A Case Study of the Fast Food Industry in New Jersey and Pennsylvania," forthcoming in American Economic Review.

Castillo-Freeman, Alida, and Richard Freeman. 1992. "When the Minimum Wage Really Bites: The Effect of the U.S.-Level Minimum on Puerto Rico." In Immigration and the Work Force, edited by George Borjas and Richard Freeman. (Chicago: University of Chicago Press), pp. 177-212.

Ehrenberg, Ronald, and Robert Smith. 1994. Modern Labor Economics: Theory and Public Policy, (New York: Harper Collins Publishers, 5th edition.)

Fleisher, Belton. 1970. Labor Economics: Theory and Evidence (Englewood Cliffs, NJ: Prentice Hall, Inc.).

Freeman, Richard, Wayne Gray, and B. Casey Ichniowski. 1981. "Low Cost Student Labor: The Use and Effects of the Subminimum Wage Provisions for Full-Time Students." Report of the Minimum Wage Study Commission, Vol. 5. Washington, D.C.: U.S. GPO, pp. 305-35.

Fritsch, Conrad. 1981. "Exemptions from the Fair Labor Standards Act, Retail Trade and Services," Report of the Minimum Wage Study Commission, Vol. 5. Washington, D.C.: U.S. GPO, pp. 11-95.

Hamermesh, Daniel and Albert Rees. 1993. The Economics of Work and Pay (New York: Harper Collins, fifth edition).

Katz, Lawrence, and Alan Krueger. 1990. "The Effect of the New Minimum Wage Law in a Low-wage Labor Market," Industrial Relations Research Association, Proceedings, vol. 43, (December), pp. 254-265. 
Katz, Lawrence, and Alan Krueger. 1992. "The Effect of the Minimum Wage on the Fast Food Industry." Industrial and Labor Relations Review Vol. 46, No. 1 (October 1992), pp. 6-21.

Klerman, Jacob. 1991. Study 12: "Employment Effect of Mandated Health Benefits".

Machen, Stephen, and Alan Manning. 1994. "The Effects of Minimum Wages on Wage Dispersion and Employment: Evidence from the U.K. Wage Councils." Industrial and Labor Relations Review, 47, No. 2, pp. 319-329.

Reynolds, Lloyd. 1965. "Wages and Employment in a Labor-Surplus Economy." American Economic Review 55, No. 1, pp. 19-39.

Reynolds, Lloyd and Peter Gregory. 1965. Wages, Productivity, and Industrialization in Prerto Rico. (Homewood, IL: Richard Irwin, Inc., first printing).

Santiago, Carlos. 1989. "The Dynamics of Minimum Wage Policy in Economic Development: A Multiple Time-Series Approach." Economic Development and Cultural Change, vol. 38 , (October): 1-30.

Spriggs, William, David Swinton, and Michael Simmons, "The Effects of Changes in the Federal Minimum Wage: Restaurant Workers in Mississippi and North Carolina," Mimeo., Economic Policy Institute, Washington, D.C., January 1992.

Taylor, Lowell and Taeil Kim. 1993. "The Employment Effect in Retail Trade of California's 1988 Minimum Wage Increase." Working Paper No. 93-16, Heinz School of Public Policy and Management, Camegie Mellon University, Pittsburgh.

U.S. Department of Commerce, Bureau of the Census. 1984. 1980 Census of Population. General Social and Economic Characteristics, Puerto Rico, 53A, PC80-1-C53A. 
</ref_section> 
Figure 1: Employment and Minimum Wage Trends

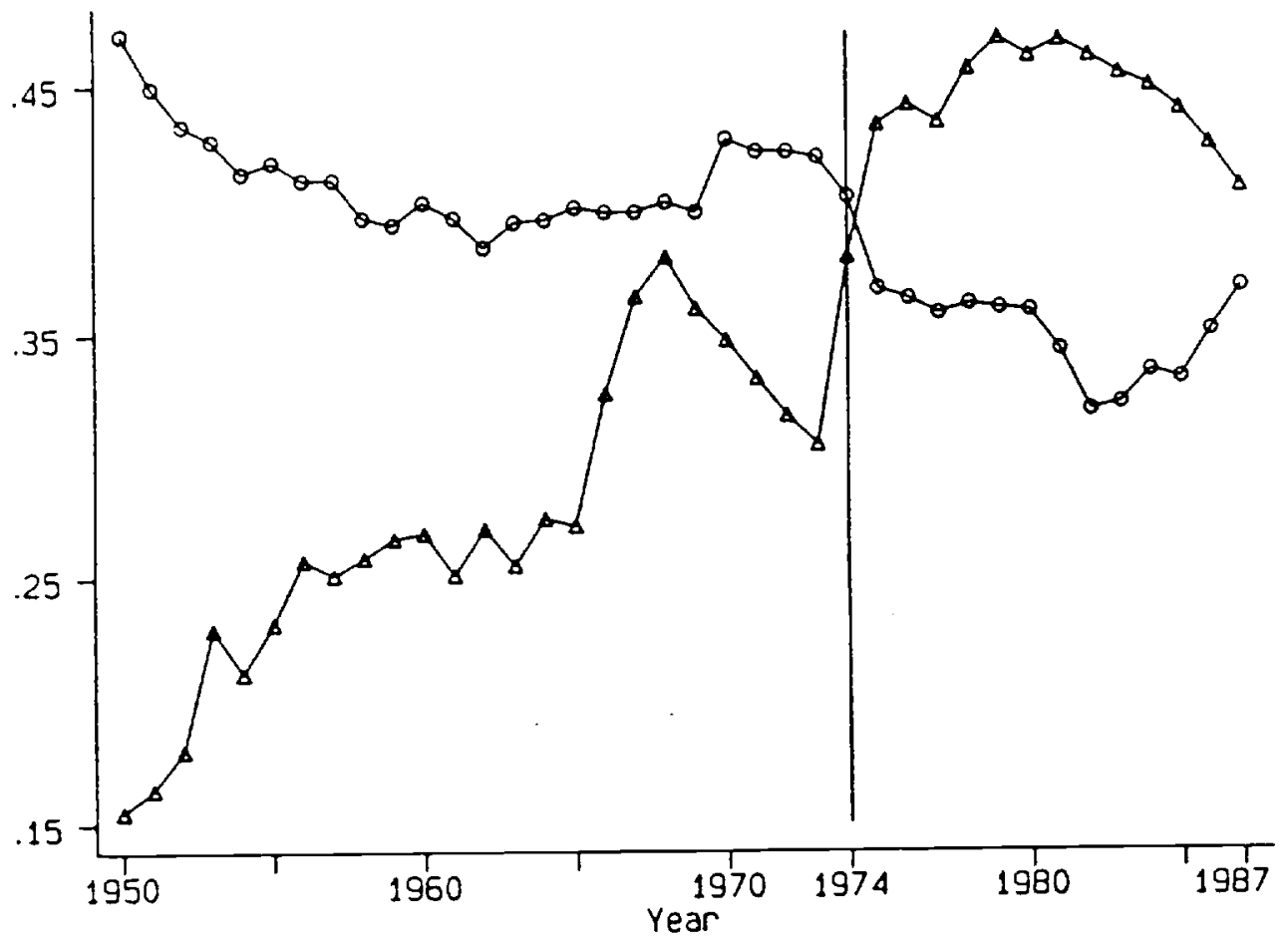

डावाa"

- Employment/Population

$\Delta$ Kaitz Index 


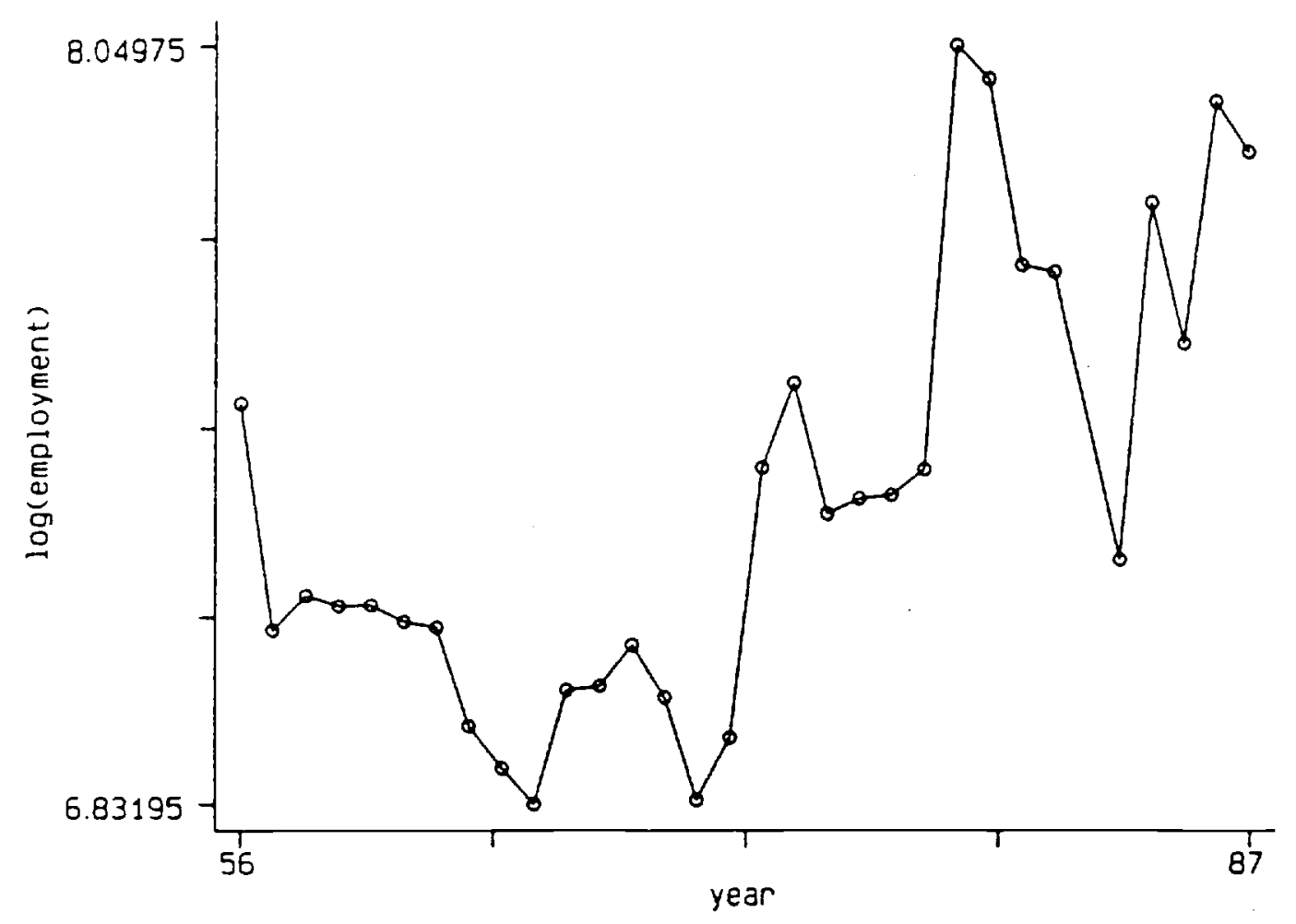

Flgure 2: Employment Variability in Industry 6 
Table 1

Examination of Puerto Rico Minimum Wage Effects, 1951-87 Aggregate Time-Series Data

Dependent Variable: Log(Employment-to-Population Ratio)

\begin{tabular}{|c|c|c|c|}
\hline Independent Var. & (1) & (2) & (3) \\
\hline $\operatorname{Ln}($ Kaitz) $t-2$ & -- & $\begin{array}{l}.03 \\
(.06)\end{array}$ & $\begin{array}{l}.03 \\
(.06)\end{array}$ \\
\hline $\operatorname{Ln}($ Kaitz) $t-1$ & -- & $\begin{array}{l}-.05 \\
(.06)\end{array}$ & $\begin{array}{l}-.04 \\
(.08)\end{array}$ \\
\hline $\operatorname{Ln}($ Kaitz) $t$ & $\begin{array}{l}-.15 \\
(.07)\end{array}$ & $\begin{array}{l}-.09 \\
(.06)\end{array}$ & $\begin{array}{l}-.08 \\
(.08)\end{array}$ \\
\hline Ln(Kaitz) $t+1$ & -- & $\begin{array}{l}-.03 \\
(.07)\end{array}$ & $\begin{array}{l}-.04 \\
(.08)\end{array}$ \\
\hline $\operatorname{Ln}($ Kaitz) $t+2$ & -- & $\begin{array}{l}-.08 \\
(.07)\end{array}$ & $\begin{array}{l}-.09 \\
(.07)\end{array}$ \\
\hline $\operatorname{AR}(1)$ & $\begin{array}{l}.65 \\
(.11)\end{array}$ & $\begin{array}{l}.47 \\
(.15)\end{array}$ & -- \\
\hline $\begin{array}{l}\text { Ln (Puerto Rican } \\
\text { GNP), Ln(U.S. GNP), } \\
\text { Time Trend }\end{array}$ & Yes & Yes & Yes \\
\hline $\begin{array}{l}\text { p-value for } 2 \text { lagged } \\
\text { and contemporaneous } \\
\text { Kaitz variables }\end{array}$ & -- & .30 & .44 \\
\hline $\begin{array}{l}\text { p-value of } 2 \text { leads } \\
\text { of Kaitz variables }\end{array}$ & -- & .32 & .18 \\
\hline R-Square & .57 & .87 & .94 \\
\hline Root MSE & .026 & .022 & .024 \\
\hline
\end{tabular}

Column 1 is a replication of the specification in column 1 of Table 6.3 of Castillo-Freeman and Freeman (1992). Sample size is 37 observations in column 1 , and 34 observations in columns 2 and 3 . $A R(1)$ represents a first-order autoregressive error term. 
Table 2

Examination of Puerto Rico Minimum Wage Effects, 1956-87

Pooled Cross-Industry/Time-Series Data

\begin{tabular}{lccc}
\hline & \multicolumn{2}{c}{ Dependent Variable and Model } \\
\cline { 2 - 4 } & $\begin{array}{c}\text { Ln(Emp) } \\
\text { Unweighted } \\
(1)\end{array}$ & $\begin{array}{c}\text { Ln(Emp) } \\
\text { Weighted } \\
(2)\end{array}$ & $\begin{array}{c}\text { Employment } \\
\text { Unweighted } \\
(3)\end{array}$ \\
\hline $\begin{array}{l}\text { Ln(Minimum } \times \text { Covg./ } \\
\text { Avg. Wage) }\end{array}$ & $\begin{array}{c}-.54 \\
(.13)\end{array}$ & $\begin{array}{c}.07 \\
(.06)\end{array}$ & $\begin{array}{c}8177 \\
(1359)\end{array}$ \\
Industry Dummies & Yes & Yes & Yes \\
Year Dummies & Yes & Yes & Yes \\
Root MSE & .48 & .31 & 5918 \\
R-Square & .87 & .96 & .95 \\
\hline
\end{tabular}

Column 1 is a replication of the specification in column 1 of Table 6.4 of Castillo-Freeman and Freeman (1992). Weights for column (2) are average industry employment, 1956-87. Sample size is 1302 observations. 
Table 3

Examination of Puerto Rico Minimum Wage Effects, 1974-87

Pooled Cross-Industry/Time-Series Data

\begin{tabular}{|c|c|c|c|}
\hline \multirow[b]{2}{*}{ Independent Var. } & \multicolumn{3}{|c|}{ Dependent Variable and Model } \\
\hline & $\begin{array}{l}\text { In (Emp) } \\
\text { Unweighted } \\
\text { (1) }\end{array}$ & $\begin{array}{l}\text { In (Emp) } \\
\text { Weighted } \\
\text { (2) }\end{array}$ & $\begin{array}{l}\text { Employment } \\
\text { Unweighted } \\
\text { (3) }\end{array}$ \\
\hline $\begin{array}{l}\text { In (Minimum } x \text { Covg./ } \\
\text { Avg. Wage) }\end{array}$ & $\begin{array}{l}-.91 \\
(.24)\end{array}$ & $\begin{array}{l}.03 \\
(.19)\end{array}$ & $\begin{array}{l}-1148 \\
(2445)\end{array}$ \\
\hline Industry Dummies & Yes & Yes & Yes \\
\hline Year Dummies & Yes & Yes & Yes \\
\hline Root MSE & .37 & .20 & 3739 \\
\hline R-Square & .95 & .98 & .99 \\
\hline
\end{tabular}

Column 1 is a replication of the specification in column 3 of Table 6.4 of Castillo-Freeman and Freeman (1992). Weights for column (2) are average industry employment, 1956-87. Sample size is 546 observations. Data for 1982 are excluded from the analysis because the Survey of Manufacturers was not conducted in 1982 . 
Table $4 a$

Employment in the Textile. Wearing Apparel, and Leather Industries

\begin{tabular}{|c|c|c|c|c|c|c|c|}
\hline & \multirow[b]{2}{*}{ ISIC } & \multicolumn{3}{|c|}{ Employment $(1,000 \mathrm{~s})$} & \multicolumn{3}{|c|}{ Percentage Change } \\
\hline & & 1973 & 1984 & 1992 & $1973-84$ & $1984-92$ & $1973-92$ \\
\hline & & \multicolumn{6}{|c|}{ Puerto Rico } \\
\hline Textiles & 321 & 7.04 & 2.41 & 3.23 & -65.8 & 34.0 & -54.1 \\
\hline Appare1 & 322 & 38.44 & 31.08 & 28.76 & -19.1 & -7.5 & -25.2 \\
\hline Leather & 323 & 2.64 & 1.57 & 1.79 & -40.5 & 14.0 & -32.2 \\
\hline Footwear & 324 & 3.64 & 3.56 & 3.7 & -2.2 & 3.9 & 1.6 \\
\hline \multirow[t]{2}{*}{ Total } & & 51.76 & 38.62 & 37.48 & -25.4 & -3.0 & -27.6 \\
\hline & & \multicolumn{6}{|c|}{ U.S. } \\
\hline Textiles & 321 & 1010 & 746 & 678 & -26.1 & -9.1 & -32.9 \\
\hline Appare 1 & 322 & 1438 & 1185 & 1018 & -17.6 & -14.1 & -29.2 \\
\hline Leather & 323 & 101 & 66 & 52 & -34.7 & -21.2 & -48.5 \\
\hline Footwear & 324 & 183 & 124 & 71 & -32.2 & -42.7 & -61.2 \\
\hline Total & & 2732 & 2121 & 1819 & -22.4 & -14.2 & -33.4 \\
\hline
\end{tabular}

Table $4 \mathrm{~b}$

Hourly Wages in the Textile, Wearing Apparel, and Leather Industries

\begin{tabular}{|c|c|c|c|c|c|c|c|}
\hline & \multirow[b]{2}{*}{ ISIC } & \multicolumn{3}{|c|}{ Avg, Wage Rate } & \multicolumn{3}{|c|}{ Percentage Change } \\
\hline & & 1973 & 1984 & 1992 & $1973-84$ & $1984-92$ & $1973-92$ \\
\hline & & \multicolumn{6}{|c|}{ Puerto Rico } \\
\hline Textiles & 321 & 1.94 & 4.31 & 5.04 & 122.2 & 16.9 & 159.8 \\
\hline Appare 1 & 322 & 1.83 & 3.93 & 4.41 & 114.8 & 12.2 & 141.0 \\
\hline Le ather & 323 & 1.66 & 4.02 & 4.44 & 142.2 & 10.4 & 167.5 \\
\hline Footwear & 324 & 1.71 & 3.97 & 4.73 & 132.2 & 19.1 & 176.6 \\
\hline \multirow[t]{2}{*}{ Average } & & 1.79 & 4.06 & 4.66 & 127.3 & 14.7 & 160.8 \\
\hline & & \multicolumn{6}{|c|}{ U.S. } \\
\hline Textiles & 321 & 2.95 & 6.46 & 8.60 & 119.0 & 33.1 & 191.5 \\
\hline Appare 1 & 322 & 2.76 & 5.55 & 6.95 & 101.1 & 25.2 & 151.8 \\
\hline Leather & 323 & 2.79 & 5.71 & 7.40 & 104.7 & 29.6 & 165.2 \\
\hline Footwear & 324 & 2.79 & 5.71 & 7.40 & 104.7 & 29.6 & 165.2 \\
\hline Average & & 2.82 & 5.86 & 7.59 & 107.5 & 29.5 & 168.8 \\
\hline
\end{tabular}

Notes: Source is Yearbook of Labor Statistics (ILO: Geneva, Switzerland, 1983 and 1993). Tables 5 and 17. For the U.S., wages are only available for leather and footwear combined. 